\title{
EKSISTENSI PESANTREN DENGAN BUDAYA PATRONASE (Hubungan Kiai Dan Santri)
}

\author{
Oleh: \\ Iwan Siswanto \& Erma Yulita \\ STAI Auliaurrasyidin Tembilahan \\ E-mail: iwansiswanto50@gmail.com
}

\begin{abstract}
ABSTRAK
Dunia pesantren dan kharisma kyai merupakan salah satu fenomena yang menarik untuk dikaji. Corak kehidupan kyai dan santri yang demikian besar membuat pesantren berfungsi multi dimensi: kyai tidak hanya berperan sebagai imam di bidang ubudiah dan ritual upacara keagamaan saja, namun sering pula diminta kehadirannya untuk menyelesaikan perkara atau kesulitan yang menimpa masyarakat. Dalam kontek ini peran kyai semakin mengakar di masyarakat ketika kehadirannya diyakini membawa berkah. Maka sudah banyak masyarakat yang mendidik anak-anak mereka ke lembaga pesantren. Hubungan Kiai-santri ada dua tipe: pertama pola hubungan guru dan murid adalah hubungan yang terjalin antara Kiai dan santri sebagaimana layaknya antara guru dengan murid dalam pola hubungan formal, kedua pola hubungan bapak-anak, yaitu pola hubungan yang terjalin antara Kiai dengan santrinya sebagaimana layaknya antara bapak dengan anak. Pola hubungan paternalisme yang terjalin antara Kiai dan santri di pesantren di pengaruhi oleh faktor intern dan ekstern. Faktor yang menyebabkan budaya patronase dapat bertahan sampai sekarang antara lain: Kepemimpinan karismatik Kiai, nilai barakah dan nilai kualat: landasan spiritual realitas sosial Kiai, ikatan seumur hidup antara Kiai dengan santri.
\end{abstract}

\section{Kata Kunci: Pesantren, paternalisme, kiai}




\section{PENDAHULUAN}

\section{A. Latar Belakang Masalah}

Pesantren berkembang dengan sebuah tradisi yang melingkupinya. Ini ditopang oleh kehadiran kiai sebagai penjaga keutuhan dan konsistensi pendiriannya. ${ }^{1}$ Watak dan ideologi kiai menyatu dengan kelembagaan pesantren. Dengan misi utama menyebarluaskan ajaran agama secara internal dalam kalangan umat Islam. Pesantren menjadi tempat utama yang dijadikan sebagai rujukan untuk belajar keagamaan. Bahkan ketika nama Indonesia belum wujud. Pesantren berkembang sebagaimana perkembangan Indonesia sekaligus mendukung pemahaman keagamaan yang inklusif. Pada sisi tertentu, pesantren juga menjaga dan merawat tradisi masyarakat setempat. Sekaligus menjadi sebuah pendukung bagi keberlangsungan komunitas. ${ }^{2}$ Tantangan pesantren adalah seiring dengan perkembangan modernitas, tentu tidak dapat melepaskan diri dari dinamika ini. Sebaliknya, pesantren justru dituntut untuk berbenah, mengadaptasi diri, dan melakukan sinergitas dengan segala dasar dan tradisi pesantren yang baik dan senantiasa relevan dengan kondisi sekarang. ${ }^{3}$

Pada sisi yang lain, modernisasi juga telah secara pelan tapi pasti mengubah kultur lokal menjadi lebih terbuka dengan mengikuti perubahan yang terjadi. Pada titik ini, budaya lokal yang dianggap sakral oleh masyarakat dan selalu dijadikan pijakan dalam setiap tindakannya lambat laun mengalami pergeseran. Pesantren sebagai lembaga Islam tradisional

${ }^{1}$ Zamakhsyari Dhofier, Tradisi Pesantren, Studi tentang Pandangan Hidup Kiai (Jakarta: LP3ES, 1990), hlm. 54

${ }^{2}$ Uktambek Sultonov, "Waqf Administration in Tashkent prior to and After the Russian Conquest: A Focus on Rent Contracts for the Kulkedas Madrasa", Islam - Zeitschrift fur Geschichte und Kultur des Islamichen Orients, Vol. 88, No. 2(2011), hlm. 324-351

${ }^{3}$ Amin Haedari, Masa Depan Pesantren Dalam Tantangan Modernitas dan Tantangan Kompleksitas Global (Jakarta: IRD Press, 2006), h. 
tertua di Indonesia juga telah melakukan transformasi. Perubahan telah menyentuh institusi ini. Pesantren yang pada dasarnya merupakan subkultur dalam kehidupan setelah masyarakat, telah bergeser perannya tidak sekedar lembaga yang mencetak Kiai atau ulama tetapi juga intelektual muslim yang diharapkan dapat melanjutkan cita-cita para pendahulunya untuk memajukan umat Islam secara keseluruhan. ${ }^{4}$

Perubahan dimaksud salah satunya dapat kita lihat dari pola hubungan Kiai dan santri yang pada awalnya kita kenal bersifat patronase yang mengandaikan pola hubungan guru dan murid. Sebagai guru, Kiai tidak hanya dikenal sebagai sosok yang mumpuni dalam ilmu pengetahuan agamanya serta memiliki akhlakul karimah, namun pada sisi yang lain Kiai juga mempunyai pengaruh yang sangat luas di dalam masyarakat melalui karisma yang mereka miliki. Tak pelak, Kiai merupakan figur dambaan umat dan senantiasa mendapat tempat yang mulia dan tinggi dalam struktur masyarakat..$^{5}$

Sebaliknya, sebagai seorang murid, santri merupakan elemen dalam tradisi pesantren yang kedudukannya lebih rendah dari Kiai. Sebagai pengikut, santri harus senantiasa taat, tawadu dan hormat kepada gurunya. Santri dalam kehidupan sehari-harinya harus senantiasa mengikuti apa yang dititahkan oleh seorang Kiai. arus modernisasi telah sedikit banyak membawa pergeseran pada perubahan Kiai dan santri di pesantren sehingga kultur yang selama ini tumbuh subur kemudian mengalami perubahan akibat perkembangan global. ${ }^{6}$

\footnotetext{
${ }^{4}$ Azyumardi Azra, Pendidikan Islam: Tradisi dan Modernisasi Menuju Milenium Baru,
} (Jakarta: Penerbit Kalimah, 2001), h. 27

${ }^{5}$ Taufik Abdullah, Agama dan Perubahan Sosial, (Jakarta: CV Rajawali, 1983), h. 12

${ }^{6}$ Faiqoh, Nyai Agen Perubahan di Pesantren, (Jakarta: Kucica, 2003), h. 25 
Sisi menarik dari model hubungan antara Kiai dengan santri adalah perasaan hormat dan kepatuhan mutlak dari seorang murid kepada gurunya. Perasaan hormat dan kepatuhan mutlak ini tidak boleh terputus, berlaku seumur hidup seorang murid. Perasaan hormat dan kepatuhan mutlak harus ditunjukkan oleh murid dalam seluruh aspek kehidupannya, melupakan ikatan dengan guru merupakan kejelekan dan akan menghilangkan barakah guru dan pada akhirnya ilmu yang dimiliki oleh seorang murid tidak bermanfaat. Hal tersebut dilakukan bukan sebagai manifestasi dari penyerahan total kepada guru yang dianggap memiliki otoritas, tetapi karena keyakinan murid kepada kedudukan guru sebagai penyalur kemurahan Tuhan yang dilimpahkan kepada murid-muridnya, baik di dunia maupun di akhirat. Pola-pola hubungan yang unik antara Kiai dan santri dipengaruhi oleh literatur pendidikan yang dipakai sebagai acuan di pesantren salah satunya adalah kitab Taklim al Mutakalim. ${ }^{7}$

Sikap hormat takdhim dan kepatuhan kepada Kiai adalah salah satu nilai pertama yang ditanamkan pada setiap santri. Kepatuhan itu mutlak dan diperluas, sehingga mencakup penghormatan kepada para ulama sebelumnya dan ulama yang mengarang kitab-kitab yang dipelajarinya. Kepatuhan ini bagi pengamat luar tampak lebih penting dari pada usaha menguasai ilmu, tetapi bagi Kiai hal itu merupakan bagian integral dari ilmu yang akan dikuasai. ${ }^{8}$ Problem hubungan antara dunia santri dan Kiai yang sering diklaim sebagai penghambat kemajuan umat adalah berkembangnya budaya patronase. "Santri” dipaksa bersikap konservatif dan berfikiran statis, karena

7 Zamakhsyari Dhofier, Tradisi Pesantren: Studi Tentang Pandangan Hidup Kiai, (Jakarta: LP3ES, 1985), h. 55

8 Martin Van Bruinessen, NU, Tradisi, Relasi Kuasa, Pencarian WahanaBaru, (Yogyakarta: LKIS, 1995), h. 18 
alam bawah sadarnya telah terpatri pada ketergantungan Kiai. Para pengasuh pondok harus membuka sekat feodalisme pesantren dengan fikiran demokratis dan kritis para santri. Model itu adalah pembebasan santri untuk bersuara lantang mengkritisi berbagai fenomena dalam masyarakat. Kritik yang diharapkan berkembang dalam budaya santri, menekankan pada keberanian membela kebenaran, rasional, tetap pada kaidah jati diri santri, sekaligus berbasis budaya masyarakat. ${ }^{9}$

Perubahan relasi Kiai dengan santri dapat kita lihat dalam ketundukan seorang santri yang mulai berkurang yang diakibatkan oleh bergesernya peran Kiai di pesantren maupun masyarakat. Sosok Kiai yang dahulu di segani dan berpengaruh karena memiliki karisma yang jarang dimiliki orang lain, mulai bergeser ketika mereka merambah ke wilayah politik dengan ikut berperan dalam kegiatan politik praktis. ${ }^{10}$

Pada sisi yang lain, seiring dengan demokratisasi di Indonesia dan kesempatan pendidikan yang tinggi oleh santri, banyak komunitas santri yang mulai tercerahkan dimana hal ini bisa kita lihat dari cara berpikir mereka yang kritis, independen dan kreatif. Hal ini tenyata berimbas terhadap hubungan Kiai-santri yang tidak lagi seperti dahulu dimana saat ini santri telah berani mengkritisi apapun yang dilakukan Kiainya yang dianggap melenceng. Karisma yang di anggap sebagai senjata ampuh untuk mempengaruhi santri juga pada tataran tertentu tidak lagi menemukan relevansinya pada saat sekarang. Sehingga praktis, Kiai sekarang sudah mulai kehilangan pengaruhnya akibat dari perannya dalam politik praktis. Konflik KH. Ma'ruf

${ }^{9}$ Hanif Dhakiri, Kiai Kampung Dan Demokrasi Lokal. Jakarta: Dewan Pengurus Pusat Partai Kebangkitan Bangsa (DPP PKB) Dengan Yayasan Kajian dan Layanan Informasi Untuk Kedaulatan Rakyat, 2007), h. 35

${ }^{10}$ Greg Fealy, Ijtihad Politik Ulama: Sejarah NU 1952-1967. Yogyakarta: LKIS, 2003), 
Amin dengan Prof. Mahfud MD serta Tokoh Nahdatul Ulama lainnya bisa kita analogikan sebagai salah satu contoh melenturnya hubungan Kiai dan santri sebagai akibat ratio excess irratio atau cara berfikir logic dalam kerangka rationalitas menjadi faktor determinan dalam memutuskan segala hal dari pada hubungan kekerabatan (kinship relationship) yang telah lama mengakar dalam kultur pesantren. Mengeroposnya unsur irratio yang dalam beberapa hal mendasari hubungan Kiai-santri ini merupakan sebuah refleksi dari fenomena bahwa hubungan Kiai dan santri saat ini sedang mengalami perubahan.

\section{B. Rumusan Masalah}

Dari latar belakang di atas, dapat diambil rumusan masalah yaitu bagaimana gambaran pola interaksi hubungan sosial kiai dan santri dan faktor-faktor apa yang menyebabkan budaya patronase dapat bertahan di pesantren sampai sekarang.

\section{PEMBAHASAN}

\section{A. Eksistensi}

Secara harfiah eksistensi artinya adalah keberadaan. Sesuatu dikatakan eksis bisa dibuktikan dengan dilihat atau dirasakan dengan indra atau juga tidak, tetapi kita bisa melihat bukti-bukti keberadaannya. Misalnya Tuhan tentu saja eksis meskipun kita tidak bisa melihatnya. Tapi kita bisa membuktikan keberadaanya dengan berpikir bagaimana bisa keberadaan segala sesuatu di alam semesta ini, tentu ada "Sesuatu Yang Maha" yang menciptakan dan mengaturnya. Bila dikaitkan dengan eksistensi budaya patronase dalam pesantren adalah keberadaan Kiai dalam mengasuh para santri. 


\section{B. Budaya}

Budaya atau kebudayaan berasal dari bahasa Sansekerta yaitu buddhayah, yang merupakan bentuk jamak dari buddhi (budi atau akal) diartikan sebagai hal-hal yang berkaitan dengan budi dan akal manusia. Dari definisi di atas maka penulis menarik kesimpulan bahwa kebudayaan atau budaya merupakan sebuah sistem, di mana sistem itu terbentuk dari perilaku, baik itu perilaku badan maupun pikiran. Dan hal ini berkaitan erat dengan adanya gerak dari masyarakat, di mana pergerakan yang dinamis dan dalam kurun waktu tertentu akan menghasilkan sebuah tatanan ataupun sistem tersendiri dalam kumpulan masyarakat. ${ }^{11}$

\section{Patronase}

Istilah patronase merupakan konsep kekuasaan yang lahir dari hubungan tidak seimbang antra patron dan klien. kata "patron" berasal dari ungkapan bahasa Spanyol yang secara etimologis berarti seseorang yang memiliki kekuasaan (power), status, wewenang dan pengaruh. Sedangkan klien berarti "bawahan" atau orang yang di perintah dan yang di suruh. Selanjutnya pola hubungan patron klien merupakan aliansi dari dua kelompok komunitas atau individu yang tidak sederajat. Baik dari segi status, kekuasaan, maupun penghasilan sehingga menempatkan klien dalam kedudukan yang lebih rendah (inferior) dan patron dalam kedudukan yang lebih tinggi (superior). Patron adalah orang yang berada dalam posisi untuk membantu klien-kliennya. ${ }^{12}$

${ }^{11}$ Koentjaraningrat, Pengantar Ilmu Antropologi, (Jakarta: Radar Jaya Offset, 2000), h. 181

12 James C. Scott, Moral Ekonomi Petani, (Jakarta: LP3S, 1983), h. 14 


\section{Sejarah Pesantren}

Pesantren merupakan lembaga pendidikan yang unik, tidak saja karena keberadaannya yang sudah sangat lama, tetapi karena kultur, metode dan jaringan yang diterapkan. Karena keunikannya, C. Geertz menyebutnya sebagai sub kultur masyarakat Indonesia (khususnya Jawa). Pendidikan pesantren memiliki kultur khas yang berbeda dengan budaya di sekitarnya, sehingga disebut sebagai sebuah sub-kultur yang bersifat idiosyncratic. Akar historis-kultural pesantren tidak terlepas dari masuk dan perkembangan Islam di Indonesia yang bercorak sufistik dan mistik. Pesantren banyak menyerap budaya masyarakat Jawa pedesaan yang pada saat itu cendrung statis dan sinkretis. Di samping karena basis pesantren adalah masyarakat pinggiran yang berada di desa, pesantren sering disebut sebagai masyarakat atau Islam tradisional.

Menurut Karel A. Steenbrink, istilah pesantren sendiri seperti halnya mengaji, bukan berasal dari istilah Arab, melainkan dari India. Demikian juga istilah pondok, langgar di Jawa, surau di Minangkabau, rangkang (dayah) di Aceh, bukan merupakan istilah Arab, tetapi dari istilah yang terdapat di India. ${ }^{13}$ Sedangkan pondok berarti rumah atau tempat tinggal sederhana yang dibuat dari bambu. ${ }^{14}$ Berbeda dengan Zamakhsari Dofier yang menyatakan bahwa pesantren berasal dari kata santri, dengan awalan pe di depan dan akhiran an, berarti tempat tinggal para santri. Zamakhsari Dhofier memprediksikan istilah pondok barangkali berasal dari pengertian asrama

${ }^{13}$ Karel A. Steenbrink, Pesantren, Madrasah, Sekolah, Pendidikan Islam dalam Kurun Modern (Jakarta: LP3S, 1994), h. 20

${ }^{14}$ Hasballah, Sejarah Pendidikan Islam di Indonesia, Lintas Sejarah Pertumbuhan dan Perkembangan (Jakarta: Raja Grafindo Persada, 1996) h. 138. 
para santri yang disebut pondok atau tempat tinggal yang dibuat dari bambu, atau barangkali dari kata Arab, funduq yang berarti hotel atau asrama. ${ }^{15}$

Terminologi pesantren dapat disimpulkan dari formulasi di atas, yaitu lembaga pendidikan Islam tertua yang telah berfungsi sebagai salah satu benteng pertahanan umat Islam, pusat dakwah dan pembangunan masyarakat muslim di Indonesia. Mastuhu mendefinisikan bahwa pesantren adalah lembaga pendidikan Islam untuk mempelajari, memahami, menghayati ajaran Islam dengan menekankan pentingnya moral keagamaan sebagai pedoman perilaku sehari-hari. ${ }^{16}$

Pesantren merupakan lembaga pendidikan dan pengajaran agama Islam, umumnya dengan cara non klasikal dimana seorang kyai atau ustadz mengajarkan ilmu agama Islam kepada santri berdasarkan kitab-kitab yang ditulis dalam bahasa Arab oleh ulama abad pertengahan, dan para santri biasanya tinggal di pondok dan asrama dalam pesantren. ${ }^{17}$

\section{E. Elemen-Elemen Pesantren}

Hampir dapat dipastikan, lahirnya suatu pesantren berawal dari beberapa elemen dasar yang selalu ada di dalamnya. Ada 5 elemen pesantren antara satu dengan lainnya tidak dapat dipisahkan. Kelima elemen tersebut meliputi kiyai, santri, pondok, masjid, dan pengajaran kitab-kitab Islam Klasik, atau yang sering disebut kitab kuning. ${ }^{18}$

${ }^{15}$ Zamakhsari Dhofier, Tradisi Pesantren, Study tentang Pandangan Hidup Kyai (Jakarta: LP3S, 1994), Cet. 6, h. 18

${ }^{16}$ Mastuhu, Dinamika Sistem Pendidikan Pesantren, Suatu Kajian Tentang Unsur dan Nilai Sistem Pendidikan Pesantren (Jakarta: Indonesia Netherlands Coorporation in Islamic Studies (INIS), 1994), h. 55

${ }^{17}$ Prasaja Sudjoko dkk, Profil Pesanteren (Jakarta: LP3S 1982), h. 10

${ }^{18}$ Amin Haedari, dkk, Masa Depan Pesantren (Jakarta: IRD Press 2005), h.25 
1. Kyai

Kyai atau pengasuh pondok pesantren merupakan elemen yang sangat esensial bagi suatu pesantren. Rata-rata pesantren yang berkembang di Jawa dan Madura sosok kiyai bergitu berpengaruh, kharismatik dan berwibawa, sehingga amat disegani oleh masyarakat di lingkungan pesantren. Di samping itu, kyai pondok pesantren biasanya juga sekaligus sebagai penggagas dan pendiri dari pesantren yang bersangkutan. Oleh karenanya, sangat wajar jika dalam pertumbuhannya, pesantren sangat bergantung pada peran seorang kyai.

2. Pondok

Pesantren pada umumnya sering juga disebut dengan pendidikan Islam tradisional di mana seluruh santrinya tinggal bersama dan belajar di bawah bimbingan seorang kyai. Asrama para santri tersebut berada di lingkungan komplek pesantren, yang terdiri dari rumah tinggal kyai, masjid, ruang untuk belajar, mengaji, dan kegiatan-kegiatan keagamaan lainnya.

3. Masjid

Seorang kyai ingin mengembangkan pesantren, pada umumnya yang pertama-tama menjadi prioritas adalah masjid. Masjid dianggap sebagai simbol yang tidak terpisahkan dari pesantren. Masjid tidak hanya sebagai tempat pengajaran kitab-kitab klasik dan aktivitas pesantren lainnya.

4. Santri

Santri adalah siswa atau murid yang belajar di pesantren. Seorang ulama bisa disebut sebagai kyai kalau memiliki pesantren dan santri yang tinggal dalam pesanteren tersebut untuk mempelajari ilmu-ilmu agama 
Islam melalui kitab-kitab kuning. Oleh karena itu, eksistensi kyai biasanya juga berkaitan dengan adanya santri di pesanterennya.

Pada umumnya, santri terbagi dalam dua kategori:

a. Santri mukim, yaitu murid-murid yang berasal dari daerah yang jauh dan menetap di pesantren.

b. Santri Kalong, para siswa yang berasal dari desa-desa di sekitar pesantren. Mereka bolak-balik (nglajo) dari rumahnya sendiri. para santri kalong berangkat ke pesantren ketika ada tugas belajar dan aktifitas pesantren lainnya.

5. Pengajaran kitab Kuning (Bahasa Arab)

Berdasarkan catatan sejarah, pesantren telah mengajarkan kitabkitab klasik, khusunya karangan-karangan madzhab Syafi'iyah. Pengajaran kitab-kitab kuning berbahasa Arab dan tanpa harkat atau sering disebut kitab Gundul. ${ }^{19}$ merupakan satu-satunya metode yang sangat formal diajarkan dalam komunitas pesantren di Indonesia. Pada umumnya, para santri datang jauh dari kampung halaman dengan tujuan ingin memperdalam kitab-kitab klasik tersebut, baik kitab Ushil Fiqh, Fiqh, Tafsir, Hadits, dan lain sebagainya. Para santri juga biasanya mengembangkan keahlian dalam berbahasa Arab (nahwu dan sharaf), guna menggali makna dan tafsir dibalik teks-teks teresebut. Dari keahlian ini, mereka dapat memperdalam ilmu-ilmu yang berbasis pada kitab-kitab klasik. ${ }^{20}$

${ }^{19}$ Kitab Gundul adalah kitab kuning yang berbahas Arab tanpa harekat sehingga dinamai oleh para santri dan masyarakatnya sebagai kitab gundul. Untuk dapat membacanya seorang santri harus menguasai dulu ilmu nahwu dan sharaf.

${ }^{20}$ Amin Haedari, dkk, Masa Depan Pesantren (Jakarta: IRD Press 2005), h.25 


\section{F. Pola Interaksi Hubungan Kiai dan Santri}

Pada pondok pesantren modern sebagai institusi pendidikan, terjadi pola interaksi Kiai dan santri yang unik yang membedakannya dengan institusi pendidikan yang lain. Hubungan yang dibentuk antara Kiai dengan santri adalah bentuk hubungan guru dan murid yang terlihat dalam hubungan bapak dan anak dan juga patron klien. Kiai sebagai patron adalah Kiai yang mampu membangun sebuah patronase dengan santrinya melalui ikatan emosional yang kuat. Patron memberikan jasa kepada santri baik pengetahuan, material dan harapan barakah serta ilmu bermanfaat. Dalam konteks kesantrian tidak ada harga yang mampu ditebus untuk membayar segala pengetahuan yang diberikan oleh Kiainya. Oleh sebab itu santri sebagai klien harus memperlihatkan tandatanda ketakdhiman terhadap Kiainya.

Model hubungan Kiai-santri ada dua tipe: (1) pola hubungan guru dan murid adalah hubungan yang terjalin antara Kiai dan santri sebagaimana layaknya antara guru dengan murid dalam pola hubungan formal, (2) pola hubungan bapak-anak, yaitu pola hubungan yang terjalin antara Kiai dengan santrinya sebagaimana layaknya antara bapak dengan anak. Dalam pandangan Kiai, santri disamping sebagai anak didiknya juga dianggap sebagai bagian dari keluarganya. Tindakan ini mendorong terbentuknya pola hubungan yang terjalin antara Kiai dengan santri sebagaimana layaknya hubungan antara bapak dan anak (pola paternalisme).

Pola hubungan paternalisme yang terjalin antara Kiai dan santri di pesantren di pengaruhi oleh faktor intern dan ekstern. Faktor intern adalah faktor yang berasal dari diri Kiai yang bersangkutan yang memandang santri sebagai amanat yang harus dididik sebagaimana anaknya sendiri. Sedangkan faktor ekstern berasal dari tradisi orang tua santri yang menyerahkan 
anaknya kepada Kiai secara langsung dan santri yang menganggap Kiai sebagaimana orang tuanya sendiri di pesantren. Pada Pondok Pesantren terjadi kesepakatan antara orang tua calon santri dengan Kiai pondok pesantren mengenai penyerahan wewenang mendidik santri dari orang tua kepada Kiai. Orang tua memberi amanah kepada Kiai untuk mendidik anaknya, sebab keterbatasan mereka. Dalam penyerahan tersebut, kesepakatan yang terjadi di antara keduanya, dengan ucapan, "saya selaku wali santri memberikan wewenang kepada Pak Kiai, agar mendidik anak saya di dalam pondok pesantren ini karena saya sama sekali tidak tau masalah agama. Kata memberi wewenang itu bermakna tidak sekedar menitipkan suatu barang, dimana pihak yang dititipi tidak mempunyai kuasa atau hak terhadap barang tersebut, tetapi pihak yang diberi wewenang mempunyai hak untuk mendidik dan mengatur perilaku atau langkah hidup anak yang diserahkan tersebut. Akan tetapi, dibalik itu ada kewajiban yang harus dipikul Kiai dalam hubungannya dengan orang tua maupun kepada Tuhan Yang Maha Esa. Kiai merasa bertanggung-jawab atas keberhasilan pendidikan santri-santri mereka dihadapan wali santri dengan dibuktikan melalui perubahan tingkah laku yang telah terjadi.

Nilai-nilai yang terdapat di pondok pesantren mengandung tiga unsure yang mengarah pada terbentuknya hubungan patronase antara Kiai dan santri, yaitu: (1) Hubungan patronase mendasarkan diri pada pertukaran yang tidak seimbang yang mencerminkan perbedaan status. Seorang klien, dalam hal ini santri telah menerima banyak jasa dari patron dalam hal ini Kiai, sehingga klien terikat dan tergantung pada patron, (2) Hubungan patronase bersifat personal. Pola resiprositas yang personal antara Kiai dan santri menciptakan rasa kepercayaan dan ketergantungan di dalam mekanisme hubungan tersebut. Hal ini dapat di lihat pada budaya 
penghormatan santri ke Kiai yang cenderung bersifat kultus individu, (3) Hubungan patron tersebar menyeluruh, fleksibel dan tanpa batas kurun waktunya. Hal ini dimungkinkan karena sosialisasi nilai ketika menjadi santri berjalan bertahun-tahun. Suatu bentuk nilai yang senantiasa dipegang teguh santri, misalnya tidak adanya keberanian santri berdebat soal apa pun dengan Kiai atau membantahnya karena bisa kualat dan ilmunya tidak bermanfaat. Suatu kutukan dirasa berat, bila sampai dilontarkan Kiai kepada santri. ${ }^{21}$

Dari penjelasan ini, dapat di ambil pengertian bahwa santri mengakui dan menerima sumber-sumber yang dimiliki Kiainya, sehingga kalau patron mempengaruhi klien, maka klien menerima dan mengakui pengaruh tersebut secara sadar atau sukarela. Sumber yang dimaksud dapat berupa tata nilai, struktur organisasi dan kekuasaan Kiai. Kemampuan Kiai menduduki posisi patron karena memiliki sumber-sumber yang tidak di miliki oleh orang yang dipengaruhi atau yang dikuasainya (klien).

Ketiga faktor yang mendasari patron klien di pondok pesantren sudah barang tentu terlihat pada tipe kepemimpinan yang dijalankan dalam mengelola lembaga pondok pesantren. Dengan penonjolan dominasi Kiai (keluarga Kiai) dan penekanan kuat tradisi, akhirnya kepemimpinan yang muncul bercorak paternalistik di mana seorang Kiai berstatus sebagai pelindung, guru dan bapak. Artinya kebersamaan para anggota, posisinya sebagai bawahan dalam pondok pesantren, sedangkan pemimpin berada di atas para anggota tersebut.

21 Abdurrahman Mas'ud, Intelektual Pesantren Perhelatan Agama dan Tradisi, (Yogyakarta: LkiS, 2004), h. 84 


\section{G. Faktor-Faktor yang Menyebabkan Budaya Patronase Dapat Bertahan di Pesantren}

1. Kepemimpinan Karismatik

Biar bagaimanapun, seorang Kiai adalah sosok ideal di mata santri-santrinya. Ia dianggap sebagai seseorang yang konsisten dalam pengamalan ajaran Islam yang telah ia sampaikan kepada santrisantrinya. Kiai sebagai sosok yang ideal dimata santri mereka adalah sosok yang perlu untuk ditauladani oleh segenap santri. Santri menganggap Kiai sebagai sosok yang diidolakan, dicintai, bahkan ditakuti sebab Kiai adalah pewaris ajaran dan perilaku Nabi. Patuh terhadap Kiai dan seperangkat nilai-nilai yang telah dilembagakan pada pondok pesantren berarti itulah kepribadian menjadi seorang muslim yang sejati. Akibatnya santri harus tunduk kepada Kiainya dengan jalan patuh terhadap aturan pondok pesantren dan kebijakan/perintah yang diberikan kepada santrinya. Dalam diri santri terdapat rasa hormat dan kepatuhan yang tinggi, hal ini karena pada dasarnya untuk mendapatkan ilmu dari Kiai maka seorang santri memiliki rasa rendah hati dan lapang dada. Hal semacam ini mengacu pada sebuah kitab klasik Taklimul Mutakalim, tertulis sebagai berikut:

"Mereka yang mencari pengetahuan hendaklah mereka ingat bahwa tidak akan pernah mendapatkan pengetahuan atau pengetahuannya tidak akan berguna, kecuali dia menaruh hormat pada pengetahuannya tersebut, dan juga menaruh hormat kepada Kiai yang telah mengajarnya”.

Dapat dipahami bahwa munculnya bentuk kepemimpinan karismatik seringkali mengabaikan nilai-nilai demokratis sebab kepemimpinan tersebut tidak rasional. Segala perintah yang diberikan 
kepada warga pesantren tradisional terutama santrinya, hampir mutlak dikerjakan selagi tidak bertentangan dengan syariat Islam. Seringkali santri tidak menyadari apa tujuan tersirat dibalik suatu perintah itu tetapi mereka meyakini bahwa perintah seorang Kiai adalah benar dan bertujuan baik bagi dirinya. Santri yakin sekali bahwa dibalik perintah orang suci itu terdapat suatu "barakah" jika dilaksanakan tetapi tidak patuh terhadap Kiai berarti ingin mendapatkan "kualat". Bentuk interaksi seperti ini menutup celah bagi seorang santri untuk melakukan kritik apalagi melawan terhadap gurunya.

2. Barakah dan Kualat: Landasan Spiritual Realitas Sosial Kiai

Ikatan guru dengan murid yang berarti ikatan Kiai dan santri sampai kapanpun status tersebut masih berlaku meskipun si santri tidak lagi belajar di Kiai tersebut. Pengucapan sebutan bekas terhadap seorang guru seringkali dianggap sebagai hal yang hina yang tidak diperkenankan. Sampai kapanpun santri adalah murid Kiai. Santri yakin jika melanggar aturan seperti ini berarti ia ingin mendapatkan "kualat" hidupnya serba tidak barakah. Seorang santri jika tidak ingin mendapatkan kualat karena berbuat tidak bijak terhadap gurunya maka ia harus melakukan penyerahan total dalam artian tunduk kepada gurunya asalkan tidak melakukan perintah yang bertentangan dengan syariat Islam. Meskipun seorang guru tidak tahu kalau muridnya telah melakukan tindakan yang lancang tetapi kualat akan diturunkan oleh Tuhan. Ini semua karena guru adalah orang yang dekat dengan Tuhan dan atas seizinNya apapun dapat menimpa terhadap murid jika melawan terhadap gurunya dan atas seizin Tuhan pula sang guru dapat menyalurkan kemurahan dari Tuhan.

3. Ikatan Seumur Hidup antara Kiai dengan Santri 
Ikatan emosi antara santri dengan Kiainya sedikit banyak telah mampu menyangga kehidupan perekonomian pesantren. Dari kalangan santri sering kali memberikan sumbangan kepada pesantrennya dalam bentuk material apapun. Demikian juga para alumni yang masih aktif bersilaturahmi terhadap Kiainya juga sering memberikan sejumlah material tertentu. Ada 2 (dua) factor yang terus melanggengkan hubungan antara Kiai dan santri.

Faktor pertama, ia melihat relasi tersebut dari segi kebudayaannya. Ia mengemukakan bahwa hubungan antara Kiai dan santrinya sangat dekat dan dalam banyak kasus, sangat emosional karena posisi karismatik Kiai dalam masyarakatnya dikuatkan oleh budaya subordinasi. Hubungan dekat ini tidak hanya terbatas selama di pesantren tetapi terus berlangsung setelah santri menjadi anggota masyarakat maka penyebaran dan kesinambungan budaya seperti itu semakin terjamin. Hubungan tidak setara ini terus terpelihara karena mantan santri terus mengunjungi Kiainya secara rutin. Alumni sebuah pesantren biasanya melakukan kunjungan rutin kepada Kiainya hanya untuk bersilaturahmi dan memperoleh karunianya. Kunjungan rutin seperti itu tidak berhenti bahkan setelah anak Kiai menggantikan ayahnya sebagai pemimpin baru pesantren. Ini karena posisi Kiai dan anaknya adalah sama dalam pandangan santri. Selain itu, pada saat anak tersebut menjadi Kiai, dengan menggantikan ayahnya maka mantan santri terdahulu biasanya mengirim anak-anaknya ke pesantren yang sekarang di kelola oleh anak Kiai tadi.

Faktor kedua yang mengikat santri dengan Kiainya terkait dengan ritual ritual keagamaan tertentu yang diadakan oleh Kiai dan dihadiri oleh mantan santri termasuk mereka dari daerah lain. Ritual ritual ini 
beragam bentuknya mulai dari peringatan wafatnya pendiri pesantren hingga festival pada akhir masa pembelajaran. Dalam dunia tarekat ada ritual-ritual keagamaan seperti "mujadahan kubro" yang dihadiri oleh ribuan pengikutnya. Di satu sisi ritual ritual itu menyediakan forum di mana orang-orang dapat mengamalkan keyakinan-keyakinan keagamaan mereka tapi di sisi lain, ia juga menjadi medium di mana hubungan antara Kiai dan santrinya atau pengikutnya dapat terus diperkuat.

Kuatnya ikatan emosional antara Kiai dengan santri telah menyebabkan hubungan diantara keduanya berlangsung selama hidup. Sampai kapanpun santri adalah murid dari Kiainya. Meskipun santri telah lulus dan kembali ke masyarakat ataupun Kiai mereka telah wafat, ada kewajiban moral untuk mendoakannya melalui ziarah kubur, seperti dalam acara chaul. Ada 2 (dua) hal yang melanggengkan hubungan Kiai santri, yaitu budaya subordinasi yang berkesinambungan dan ritual ritual yang diselenggarakan oleh pondok pesantren. Budaya subordinasi menurutnya mengandung maksud hubungan yang tidak setara antara guru dan murid yang kemudian dilestarikan hingga si santri mempunyai anak-anak dan kemudian anak-anak tersebut di pondokkan di pesantren yang sama sehingga menjadi murid Kiai yang bersangkutan. Sedangkan ritual ritual yang diadakan di pondok seperti chaul, akhirussanah dan silaturahmi lebaran yang seringkali mengundang dan dihadiri oleh santrisantri alumni ikut pula mempererat hubungan Kiai dan santri tersebut. 


\section{PENUTUP}

\section{A. Kesimpulan}

Model hubungan Kiai dan santri ada dua tipe: pertama, pola hubungan guru-murid adalah hubungan yang terjalin antara Kiai dan santri sebagaimana layaknya antara guru dengan murid dalam pola hubungan formal. Kedua, pola hubungan bapak dan anak, yaitu pola hubungan yang terjalin antara Kiai dengan santrinya sebagaimana layaknya antara bapak dengan anak. Pola hubungan paternalisme yang terjalin antara Kiai dan santri di pesantren di pengaruhi oleh faktor intern dan ekstern. Faktor intern adalah faktor yang berasal dari diri Kiai yang bersangkutan yang memandang santri sebagai amanat yang harus dididiknya sebagaimana anaknya sendiri. Sedangkan faktor ekstern berasal dari tradisi orang tua santri yang menyerahkan anaknya kepada Kiai secara langsung dan santri yang menganggap Kiai sebagaimana orang tuanya sendiri di pesantren.

Faktor yang menyebabkan budaya patronase dapat bertahan sampai sekarang antara lain: Kepemimpinan karismatik Kiai, nilai barakah dan nilai kualat: landasan spiritual realitas sosial Kiai, ikatan seumur hidup antara Kiai dengan santri. Faktor pertama, ia melihat relasi tersebut dari segi kebudayaannya. Ia mengemukakan bahwa hubungan antara Kiai dan santrinya sangat dekat dan dalam banyak kasus, sangat emosional karena posisi karismatik Kiai dalam masyarakatnya dikuatkan oleh budaya subordinasi. Hubungan dekat ini tidak hanya terbatas selama di pesantren tetapi terus berlangsung setelah santri menjadi anggota masyarakat maka penyebaran dan kesinambungan budaya seperti itu semakin terjamin. Hubungan tidak setara ini terus terperlihara karena mantan santri terus mengunjungi Kiainya secara rutin. Alumni sebuah pesantren biasanya melakukan kunjungan rutin kepada Kiainya hanya untuk bersilaturahmi dan 
memperoleh karunianya. Faktor kedua yang mengikat santri dengan Kiainya terkait dengan ritual ritual keagamaan tertentu yang diadakan oleh Kiai dan dihadiri oleh mantan santri termasuk mereka dari daerah lain. Ritual ritual ini beragam bentuknya mulai dari peringatan wafatnya pendiri pesantren hingga festival pada akhir masa pembelajaran. Dalam dunia tarekat ada ritual ritual keagamaan seperti "mujadahan kubro" yang dihadiri oleh ribuan pengikutnya. Di satu sisi ritual-ritual itu menyediakan forum di mana orangorang dapat mengamalkan keyakinan-keyakinan keagamaan mereka tapi di sisi lain, ia juga menjadi medium di mana hubungan antara Kiai dan santrinya atau pengikutnya dapat terus diperkuat.

\section{DAFTAR PUSTAKA}

Abdullah, Taufik. 1983. Agama dan Perubahan Sosial. Jakarta: CV Rajawali.

Azra, Azyumardi. 2001. Pendidikan Islam: Tradisi dan Modernisasi Menuju Milenium Baru. Jakarta: Penerbit Kalimah.

Bruinessen, Martin Van. 1995. NU, Tradisi, Relasi Kuasa, Pencarian WahanaBaru. Yogyakarta: LKIS.

Dhakiri, Hanif. 2007. Kiai Kampung Dan Demokrasi Lokal. Jakarta: Dewan Pengurus Pusat Partai Kebangkitan Bangsa (DPP PKB) Dengan Yayasan Kajian dan Layanan Informasi Untuk Kedaulatan Rakyat.

Dhofier, Zamakhsyari. 1990. Tradisi Pesantren, Studi tentang Pandangan Hidup Kiai. Jakarta: LP3ES.

Faiqoh. 2003. Nyai Agen Perubahan di Pesantren. Jakarta: Kucica.

Fealy, Greg. 2003. Ijtihad Politik Ulama: Sejarah NU 1952-1967. Yogyakarta: LKIS.

Haedari, Amin. 2006. Masa Depan Pesantren Dalam Tantangan Modernitas dan Tantangan Kompleksitas Global. Jakarta: IRD Press. 
Haedari, Amin. Dkk. 2005. Masa Depan Pesantren. Jakarta: IRD Press.

Hasballah. 1996. Sejarah Pendidikan Islam di Indonesia, Lintas Sejarah Pertumbuhan dan Perkembangan. Jakarta: Raja Grafindo Persada.

Koentjaraningrat. 2000. Pengantar Ilmu Antropologi. Jakarta: Radar Jaya Offset.

Mas'ud, Abdurrahman. 2003. Intelektual Pesantren Perhelatan Agama dan Tradisi. Yogyakarta: LkiS.

Mastuhu. 1994. Dinamika Sistem Pendidikan Pesantren, Suatu Kajian Tentang Unsur dan Nilai Sistem Pendidikan Pesantren. Jakarta: Indonesia Netherlands Coorporation in Islamic Studies (INIS).

Scott, James C. 1983. Moral Ekonomi Petani. Jakarta: LP3S.

Steenbrink, Karel A. 1994. Pesantren, Madrasah, Sekolah, Pendidikan Islam dalam Kurun Modern. Jakarta: LP3S.

Sudjoko, Prasaja. dkk. 1982. Profil Pesanteren. Jakarta: LP3S.

Sultonov, Uktambek 2011. "Waqf Administration in Tashkent prior to and After the Russian Conquest: A Focus on Rent Contracts for the Kulkedas Madrasa", Islam Zeitschrift fur Geschichte und Kultur des Islamichen Orients 